\title{
Why has unemployment risen in the New South Africa? ${ }^{1}$
}

\author{
Abhijit Banerjee*, Sebastian Galiani†, Jim Levinsohn¥, \\ Zoë McLaren‡ and Ingrid Woolard§ \\ *Massachusetts Institute of Technology, Cambridge, Massachusetts, USA. \\ +Washington University in St. Louis, Missouri, USA. \\ łUniversity of Michigan, Ann Arbor, Michigan, USA. E-mail: jamesl@umich.edu. \\ §University of Cape Town, Cape Town, South Africa.
}

\section{Abstract}

We document the rise in unemployment in South Africa since the transition in 1994. We describe how changes in labour supply interacted with stagnant labour demand to produce unemployment rates that peaked between 2001 and 2003. Meanwhile, compositional changes in employment at the sectoral level widened the gap between the skill-level of the employed and the unemployed. Using nationally representative panel data, we show that stable unemployment rates mask high individual-level transition rates in labour market status. Our analysis highlights several key constraints to addressing unemployment in South Africa. We conclude that unemployment is near equilibrium levels and is unlikely to selfcorrect without policy intervention.

JEL classifications: J08, J68, O12.

Keywords: South Africa, unemployment.

Received: January 29, 2008; Acceptance: June 25, 2008

${ }^{1}$ We thank David Deming, Matias Horenstein, Vimal Ranchhod and Paulo Somaini for research assistance and an anonymous referee for helpful comments and suggestions. Special thanks to Jairo Arrow, Jacques deKlerk and the rest of the team at Statistics South Africa for constructing the LFS panel. 


\section{Introduction}

Regardless of the measure used, too many South Africans are unemployed. Even by a narrow definition, about 26 percent of the labour force is currently unemployed. It has not always been this way. Unemployment appeared to be fairly low through the 1970s and 1980s, although data limitations preclude certainty. At the time of democratic transition in 1994, unemployment was substantially lower than it is today. A nationally representative survey conducted just before the transition indicated that unemployment was 13 percent, but by the end of the decade, unemployment had jumped to almost 30 percent. This article focuses on the causes of this increase and the reasons why unemployment has remained high.

We rely on a decade of detailed nationally representative household surveys to inform our inquiry, and we place a greater emphasis on the more recent data. We begin our analysis in Section 2 by documenting unemployment and the characteristics of the labour force in South Africa. This section puts forth the set of facts that lay the groundwork for our explanation of the current high unemployment rate. We find that the supply of labour increased after the fall of apartheid. In particular, there was an unprecedented influx of African women into the labour market. On the whole, these new entrants into the labour market tended to be relatively unskilled. At about the same time, the overall demand for labour levelled-off and, in the mining and agricultural sectors, the demand for labour, especially less-skilled labour, fell. Skill-biased technical change further contributed to the decline in the demand for unskilled labour. While unskilled labour demand was shrinking, there was a huge influx of relatively unskilled labour, and unemployment among the less-skilled and/or less-experienced workers ballooned.

Section 3 investigates the compositional changes in employment at the sectoral level and the accompanying trends in wages. The employment share and real wages of high-skilled workers have increased as industries shifted towards more skilled workers. The unemployed are becoming, on average, less-skilled as unemployment rates for those with a matric or less increase (see footnote 6). As the gap widens between the skill level of the employed and that of the unemployed, policies to transition the unemployed into the labour market face even greater hurdles.

Section 4 moves beyond the sectoral viewpoint of Section 3 and examines unemployment at the level of the individual. Having documented the rather bleak picture of the labour market in Sections 2 and 3, we next investigate why unemployment has persisted. In the simplest economic models, when supply increases while demand is falling, we expect prices (wages) to fall to clear the market. While there is some evidence that real wages fell in South Africa during the worst years of unemployment, the nominal decline that would have been necessary to clear the labour market was simply too large to be politically or 
socially acceptable. Furthermore, there were institutional constraints that kept wages from declining as much as they otherwise might have. We find, for example, a persistent union wage differential suggesting that unions are propping up wages for union members. While this is good news for employed union members, it poses additional challenges to addressing the unemployment problem.

One way in which unemployment might have been reduced would have been for South Africa to 'inflate' its way out of the morass. With inflation and fairly constant nominal wages, the real declines could, in principle, clear the market. However, inflation and the resulting decline in real wages were not politically acceptable either since South Africa was under intense scrutiny by the international community in the years after transition.

There are at least three reasons why unemployment has remained at such high levels. First, job search appears to be less effective for African job seekers compared to whites, which is likely due to the spatial separation between the business centres and the outlying areas where Africans reside. The lack of affordable public transportation undoubtedly contributes to this problem. After decades of institutionalized racial discrimination, remnants surely persist, and, when combined with high search costs, even a small degree of discrimination could cause the high unemployment rates we observe. Second, while we might expect the informal sector to provide employment, especially in these outlying areas, and absorb many who would otherwise be unemployed, it has not. Unlike other African countries, the informal sector has grown very little as participation and unemployment rates have risen. Crime rates and high startup costs for small businesses probably impede its growth. As for the role of reservation wages in the unemployment story, it remains fairly opaque. Our results suggest that the generous Old Age Pension scheme contributes to the unemployment problem as pension income is often used to support other members of the household, especially younger workers. We also consider whether recent changes in the returns to education may be propping up the reservation wage.

We conclude that while there may be some elements of the recent increase in unemployment that result from temporary 'shocks' away from the equilibrium rate, most of the evidence points to structural changes in the labour market that resulted from the dismantling of apartheid. The evidence suggests that the equilibrium rate of unemployment has in fact increased. Active policy is necessary because the problem is not likely to be self-correcting.

\section{The structure of unemployment and labour input}

In this section we describe some of the key patterns in the data that motivate our analysis. Table 1 presents the recent trends in participation, employment and 
Table 1. Participation, employment and unemployment rates (\%)

\begin{tabular}{lcccccc}
\hline Year & \multicolumn{3}{c}{ ILO classification } & & \multicolumn{2}{c}{ Broad classification } \\
\cline { 2 - 3 } & Participation & Employment & Unemployment & & Participation & Unemployment \\
\hline 1995 & 51.4 & 43.3 & 15.6 & & 60.3 & 28.2 \\
1997 & 48.2 & 37.5 & 22.1 & & 60.6 & 38.0 \\
1999 & 55.4 & 41.7 & 24.8 & & 69.0 & 39.9 \\
2001 & 59.4 & 41.4 & 30.3 & & 72.1 & 42.5 \\
2003 & 56.8 & 40.6 & 28.6 & & 70.6 & 42.5 \\
2005 & 57.2 & 41.9 & 26.7 & & 71.2 & 41.1 \\
\hline
\end{tabular}

Notes: All statistics are for population 16-64 years old.

Source: Authors' calculations using the October Household Survey and the September wave of the Labor Force Survey.

unemployment for the working-age population. ${ }^{2}$ Several interesting facts emerge. First of all, unemployment, irrespective of the measure adopted, is extremely high, and has increased substantially since the African National Congress came to power after South Africa's first democratic elections in 1994. Using the ILO definition, unemployment doubled between 1995 and 2001, going from an already high unemployment rate of 15.6 percent to 30.3 percent. Since then, it has declined but was still 26.7 percent in 2005 - substantially higher than in $1995 .^{3}$ We use the ILO definition for international comparability, however, this definition almost certainly understates the magnitude since discouraged workers are part of the unemployment problem. Second, labour force participation also substantially increased since the end of apartheid. Using the ILO definition, it increased by 6 percentage points, which, over a decade, represents a large shock to the labour market. ${ }^{4}$ Evidence from international comparisons suggests that even among African countries, which

\footnotetext{
2 The International Labour Organization (ILO) definition of unemployment classifies working age individuals as being in the labour force if during a week of reference they were employed or wanted to work and were available to start working within a week but also had actively looked for work during the past four weeks. This is also referred to as the narrow definition. We also present statistics that use an extended or broader definition of labour force participation and unemployment by eliminating the requirement of having actively searched for a job in order for an individual to be classified as unemployed.

${ }^{3}$ Our statistics are not exactly the same as those officially published by STATS-SA since we restrict our estimates to the population aged 16-64 years.

${ }^{4}$ A concern with the 1995 October Household Survey is that several districts in KwaZulu/Natal were not surveyed because they were considered too dangerous for the survey teams. The population in these areas was about 3 million, so the omission may be important. Survey weights were calculated to compensate for this problem (see Butcher and Rouse, 2001). However, the fact that these workers are not represented must be kept in mind when comparing later periods to 1995.
} 
Table 2. Participation, employment and unemployment by gender (\%)

\begin{tabular}{cccccccc}
\hline Year & \multicolumn{3}{c}{ Male } & & \multicolumn{3}{c}{ Female } \\
\cline { 2 - 3 } \cline { 6 - 7 } \cline { 6 - 7 } & Participation & Employment & Unemployment & Participation & Employment & Unemployment \\
\hline 1995 & 62.1 & 54.5 & 12.3 & & 41.1 & 32.7 & 20.5 \\
1997 & 57.9 & 47.7 & 17.7 & & 39.2 & 28.2 & 28.1 \\
1999 & 63.3 & 50.2 & 20.7 & & 48.1 & 33.8 & 29.7 \\
2001 & 66.5 & 48.7 & 26.7 & & 53.0 & 34.8 & 34.4 \\
2003 & 64.2 & 47.7 & 25.6 & & 50.3 & 34.2 & 31.9 \\
2005 & 65.2 & 50.5 & 22.6 & & 49.8 & 34.0 & 31.7 \\
\hline
\end{tabular}

tend to have lower employment rates and higher unemployment rates than OECD and Latin American countries, South Africa performs poorly. ${ }^{5}$

Table 2 presents the recent trends in participation, employment and unemployment by gender. As is often the case, males are more likely to participate in the labour market and less likely to be unemployed. Indeed, female unemployment rates are about 50 percent higher than those for males, a figure that is not unusual relative to other labour markets in the world. The table also shows that the participation gender gap narrowed between 1995 and 2005.

We turn next to labour market performance by educational attainment. We classify the population into four education groups: Less than matric, matric, some post-matric education and tertiary education completed. ${ }^{6}$ There are few surprises. Table 3 shows that higher education is correlated with better employment outcomes and greater labour market participation. The largest increase in participation from 1995 to 2005 is for workers with a matric or less. This group has also seen its employment rate actually decline from 54 percent to 49.7 percent during this period. Consequently, their unemployment rate almost doubled, from 15.2 percent to 28.2 percent. Only those with a university degree have reasonably low unemployment rates.

Table 4 categorizes the unemployed in 2005 by the duration of their unemployment spell and whether they have worked before. Most strikingly, almost 60 percent of the unemployed have never held a job before. Long-term unemployment is clearly a problem: of those who have worked before, 58.6 percent have been unemployed for a year or more, whereas this figure is 68.3 percent for those who have never worked. It is important to note that young people make up the majority of those who have never worked.

\footnotetext{
${ }^{5}$ See Banerjee et al. (2007) for descriptive statistics.

${ }^{6}$ The matriculation exam, or matric, is the South African high-school leaving exam. Holding a matric is approximately equal to having a high-school education.
} 
Table 3. Participation, employment and unemployment by educational level (\%)

\begin{tabular}{|c|c|c|c|c|c|c|c|c|c|c|c|c|}
\hline \multirow[t]{2}{*}{ Year } & \multicolumn{3}{|c|}{ Less than matric } & \multicolumn{3}{|c|}{ Matric } & \multicolumn{3}{|c|}{ Post-matric } & \multicolumn{3}{|c|}{ College } \\
\hline & $\begin{array}{c}\text { Participa } \\
\text {-tion }\end{array}$ & $\begin{array}{c}\text { Employ } \\
\text {-ment }\end{array}$ & $\begin{array}{c}\text { Unemploy } \\
\text {-ment }\end{array}$ & $\begin{array}{c}\text { Participa } \\
\text {-tion }\end{array}$ & $\begin{array}{l}\text { Employ } \\
\text {-ment }\end{array}$ & $\begin{array}{c}\text { Unemploy } \\
\text {-ment }\end{array}$ & $\begin{array}{c}\text { Participa } \\
\text {-tion }\end{array}$ & $\begin{array}{c}\text { Employ } \\
\text {-ment }\end{array}$ & $\begin{array}{c}\text { Unemploy } \\
\text {-ment }\end{array}$ & $\begin{array}{c}\text { Participa } \\
\text {-tion }\end{array}$ & $\begin{array}{c}\text { Employ } \\
\text {-ment }\end{array}$ & $\begin{array}{c}\text { Unemploy } \\
\text {-ment }\end{array}$ \\
\hline 1995 & 44.8 & 36.6 & 18.4 & 63.7 & 54.0 & 15.2 & 80.6 & 76.8 & 4.6 & 85.8 & 84.0 & 2.1 \\
\hline 1997 & 41.3 & 30.8 & 25.4 & 62.5 & 48.7 & 21.9 & 80.0 & 73.7 & 7.9 & 83.6 & 80.4 & 3.9 \\
\hline 1999 & 47.8 & 34.6 & 27.7 & 68.8 & 50.4 & 26.7 & 85.0 & 74.3 & 12.6 & 87.4 & 82.2 & 6.0 \\
\hline 2001 & 51.8 & 34.4 & 33.6 & 73.3 & 49.7 & 32.3 & 85.9 & 72.4 & 15.7 & 90.1 & 83.2 & 7.7 \\
\hline 2003 & 48.4 & 33.1 & 31.6 & 71.2 & 49.2 & 30.9 & 89.1 & 76.1 & 14.6 & 89.7 & 85.6 & 4.6 \\
\hline 2005 & 49.2 & 34.2 & 30.4 & 69.2 & 49.7 & 28.2 & 86.2 & 76.1 & 11.7 & 88.5 & 85.6 & 3.3 \\
\hline
\end{tabular}


Table 4. Unemployment by previous working status and incomplete duration spell (\%)

\begin{tabular}{|c|c|c|c|}
\hline \multicolumn{2}{|c|}{ Worked before } & \multicolumn{2}{|c|}{ Never worked } \\
\hline \multicolumn{2}{|c|}{41.1} & \multicolumn{2}{|c|}{58.9} \\
\hline$<1$ year & $\geq 1$ year & $<1$ year & $\geq 1$ year \\
\hline 41.4 & 58.6 & 31.7 & 68.3 \\
\hline
\end{tabular}

\subsection{Trends in labour supply}

Figure 1 documents the increase in labour force participation rates in the late 1990s, notably among females whose participation rate increased by 10 percentage points. Participation rates have decreased since 2000, however some of this may be due to incomparability of the OHS and LFS surveys. ${ }^{7}$ The main message of this figure is that the entire secular movement in unemployment prior to 2005 can be accounted for by changes in participation. ${ }^{8}$ The respective shares of Africans, young people, and females increased considerably. Indeed, we estimate that changes in composition of the labour force account for 31 percent of the increase in unemployment between 1995 and 2005. ${ }^{9}$

In Figure 2 we present the actual unemployment series along with a counterfactual series that is constructed by holding the labour force participation rate constant at 1995 levels. The counterfactual rate is approximately the same at the beginning and end of the period (1995-2005) with a rise and fall mirroring changes in participation.

\subsection{Patterns in labour demand}

We now turn our attention to the evolution of the composition of employment in South Africa. ${ }^{10}$ The data show a dismal employment performance over the period from 1970 to 2005 (see Table 5). Total employment only increased by 57 percent, which implies an annualized growth rate of 1.3 percent per year. The number of employees only increased 48.6 percent over the same period, which implies an annualized growth rate of 1.14 percent per year, however much of this appears to

\footnotetext{
${ }^{7}$ The sharp increase in participation between 1999 and 2000 may be partly attributed to changes in survey methodology or sampling frame between the OHS and LFS.

${ }^{8}$ See Casale and Posel (2002) for further discussion.

${ }^{9}$ See Banerjee et al. (2007) for details.

${ }^{10}$ We rely on the analysis in Bhorat (2004) for trends in employment between 1970 and 1995 (using the Census of 1970 and the 1995 OHS) and extend the analysis using the Labour Force Surveys of September 2000 and March 2005.
} 
Figure 1. Participation and employment rates.
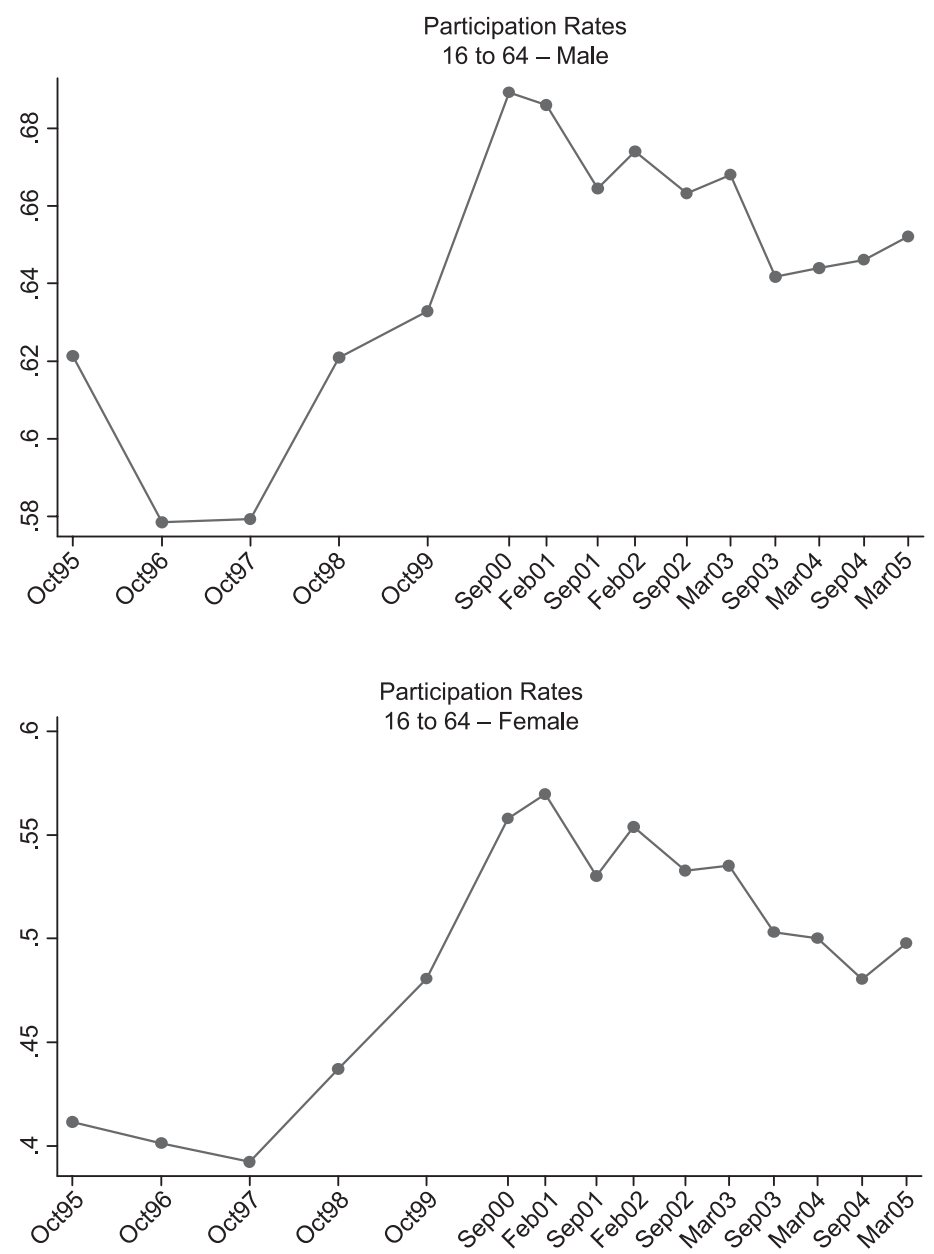

be informal sector employment. ${ }^{11}$ Contrasting this employment growth with the fact that the population aged 14-65 grew at 2.68 percent per year paints a clear picture of the role stagnant labour demand played in the unemployment problem. To make matters worse, capital-labour ratios increased in every industry from the

${ }^{11}$ Casale, Muller and Posel (2004) conclude that while a 'substantial' part of the employment growth from 1995 onwards is 'real', changes in data capture methods and definitions of employment between surveys do contribute to the increase. 
Figure 2. Actual and counterfactual unemployment rates.

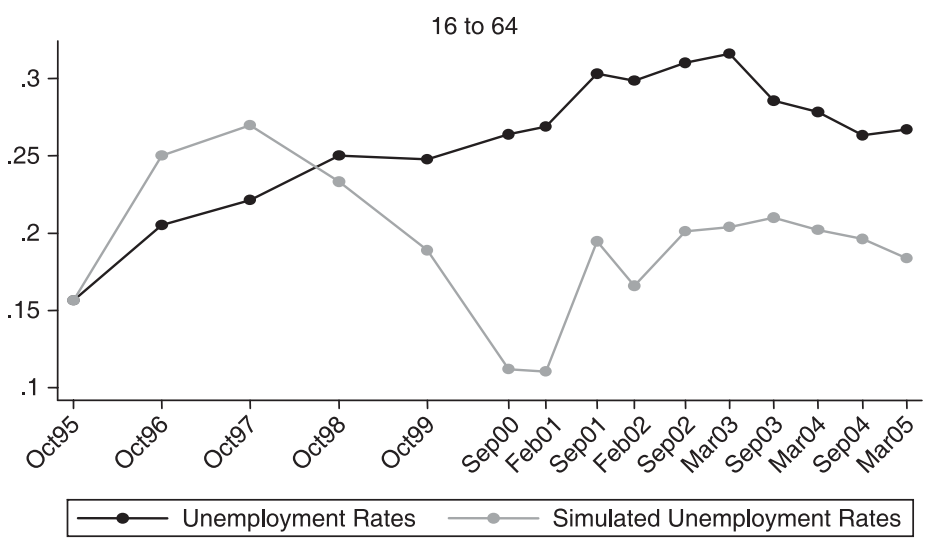

Note: 1995 participation rate was used.

Table 5. Total employment

\begin{tabular}{lcrcr}
\hline Source and Year & Census 1970 & OHS 1995 & LFS Sep 2000 & LFS Mar 2005 \\
\hline Total employment & $7,709,476$ & $10,151,548$ & $11,969,273$ & $12,107,554$ \\
Employee & $6,294,614$ & $8,659,211$ & $9,084,569$ & $9,353,677$ \\
Self employee & 572,264 & 795,649 & $1,878,453$ & $1,899,868$ \\
Domestic workers & 842,598 & 696,688 & $1,006,251$ & 854,009 \\
Unemployment & 303,165 & $1,998,914$ & $4,088,846$ & $4,288,875$ \\
\hline
\end{tabular}

Sources: Census 1970, OHS 1995 and LFS September 2000 and March 2005.

late 1980s at least through the end of the 1990s. ${ }^{12}$ Alleyne and Subramanian (2001) conclude that labour is being under utilized due to its high cost relative to capital.

\section{Employment trends by sector and skill level: 1970-2005}

The poor growth in total employment between 1970-2005 is associated with substantial structural change. The primary sector - mainly Agriculture and Mining - was shedding labour throughout the period while Finance, Wholesale and Retail Sales and Community, Social and Personal Services increased employment (see Table 6). ${ }^{13}$ Thus, the sectoral composition of employment changed substantially in South Africa.

12 Alleyne and Subramanian (2001).

${ }^{13}$ In this section we adopt the same educational classification as Bhorat (2000). Individuals who earned a diploma or a certificate are considered as having tertiary education. 
Table 6. Evolution of relative employment by industry (\%)

\begin{tabular}{|c|c|c|c|c|c|c|c|c|}
\hline \multirow[t]{2}{*}{ Industry } & \multicolumn{4}{|c|}{ Total employment } & \multicolumn{4}{|c|}{ Employees } \\
\hline & 1970 & 1995 & 2000 & 2005 & 1970 & 1995 & 2000 & 2005 \\
\hline Agriculture & 33 & 14 & 17 & 11 & 33 & 14 & 10 & 8 \\
\hline Mining & 9 & 5 & 5 & 4 & 9 & 6 & 7 & 5 \\
\hline Manufacturing & 14 & 16 & 15 & 15 & 14 & 17 & 17 & 17 \\
\hline Utilities & 1 & 1 & 1 & 1 & 1 & 1 & 1 & 1 \\
\hline Construction & 6 & 5 & 6 & 7 & 6 & 5 & 6 & 8 \\
\hline Wholesale and retail & 9 & 19 & 23 & 25 & 9 & 17 & 18 & 19 \\
\hline Transport & 4 & 6 & 5 & 5 & 4 & 6 & 6 & 6 \\
\hline Finance & 3 & 7 & 9 & 11 & 3 & 7 & 11 & 11 \\
\hline Community & 21 & 26 & 19 & 21 & 21 & 28 & 24 & 24 \\
\hline
\end{tabular}

Table 7. Evolution of relative employment by education level (\%)

\begin{tabular}{|c|c|c|c|c|c|c|c|c|}
\hline \multirow[t]{2}{*}{ Education level } & \multicolumn{4}{|c|}{ Total employment } & \multicolumn{4}{|c|}{ Employees } \\
\hline & 1970 & 1995 & 2000 & 2005 & 1970 & 1995 & 2000 & 2005 \\
\hline None & 38 & 7 & 7 & 5 & 38 & 7 & 5 & 4 \\
\hline Some primary & 31 & 20 & 24 & 18 & 31 & 21 & 20 & 17 \\
\hline Some secondary & 23 & 31 & 30 & 29 & 23 & 31 & 30 & 29 \\
\hline Complete secondary & 6 & 24 & 21 & 29 & 6 & 24 & 24 & 31 \\
\hline Tertiary & 1 & 17 & 18 & 18 & 1 & 17 & 21 & 19 \\
\hline
\end{tabular}

Agriculture went from 33 percent of total employment to only 11 percent while Wholesale and Retail Sales increased from 9 to 25 percent, and employment in the financial sector also increased from 3 to 11 percent. This altered the composition of employment in terms of educational attainment, favoring more skilled workers (see Table 7). It also appears plausible that displaced workers from agriculture and mining were unable to relocate to other regions where jobs might be available, which could be why there are so many discouraged workers in rural areas. ${ }^{14}$

\subsection{The evolution of wages}

It is safe to say that average real wages in South Africa have been stable or have decreased slightly between 1995 and 2005. We estimate that real wages decreased

${ }^{14}$ See Banerjee et al. (2007) for further analysis of the urban/rural dichotomy. 
Figure 3. Real wage trends.
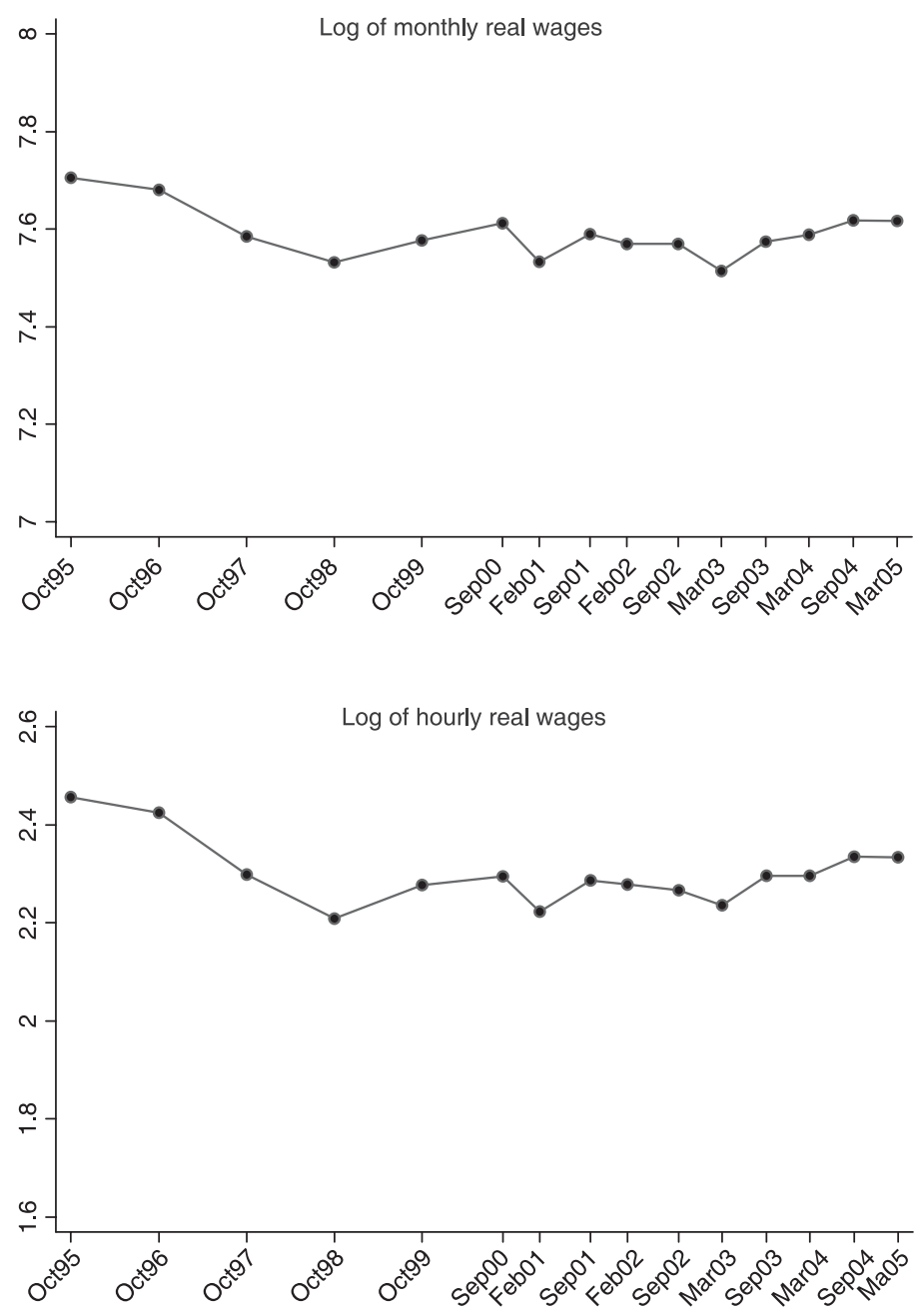

by approximately 10 percent during this time, because of a decline from 1995 to 1998 and a recovery at the end of the period (see Figure 3$).{ }^{15}$ This estimate contrasts with that of Burger and Yu (2006) who estimate an increase of 4 percent over the same period, but is consistent with results in Hoogeveen and Özler (2005), who find that

${ }^{15}$ We consider only full-time employees to exclude most informal salaried workers that were captured differentially in the early surveys. We also drop extremely high wage observations that are probably the result of coding errors. 
per capita growth of household expenditures grew only 0.5 percent between 1995 and 2000. ${ }^{16}$ Using these data, Kingdon and Knight (2006a) find that the hourly wage elasticity to local (broad) unemployment rates is approximately -0.018 when unemployment is between 10 and 30 percent, which, surprisingly, is similar to elasticities in OECD countries with less rigid employment law. However, above 30 percent unemployment, the elasticity goes to zero. It is important to note that the trends in average real wages hide the evolution of a composition effect: while the real wages of most groups declined, the share of high-income workers increased during this period, propping up the average real wage. ${ }^{17}$ This is consistent with Leibbrandt, Levinsohn and McCrary (2005), who find that the decline in real individual income is attributable to the decline in returns to individual endowments (attributes).

\subsection{Labour unions}

Labour unions have an important role in determining the evolution of wages because of their sizeable membership and substantial economic and political force in South Africa. ${ }^{18}$ In Table 8 we present the share of employees that were union members; it appears to have been stable since 1993. Unionization rates are highest

Table 8. Share of employees that are union members

\begin{tabular}{lrrrrr}
\hline Industrial sector & $\mathbf{1 9 9 3}$ & Oct. 1995 & Oct. 1998 & Sep. 2000 & Feb. 2004 \\
\hline Agriculture & 4.5 & 6.9 & 9.5 & 8.7 & 6.7 \\
Mining & 73.1 & 70.7 & 72.9 & 70.0 & 78.5 \\
Manufacturing & 48.0 & 45.7 & 45.6 & 41.5 & 40.2 \\
Electricity and water & 36.8 & 41.6 & 41.7 & 36.0 & 32.3 \\
Construction & 23.5 & 18.5 & 15.0 & 12.1 & 10.9 \\
Wholesale, retail, hotel and restaurants & 26.4 & 23.7 & 22.7 & 18.3 & 19.1 \\
Transport, communication and finance & 29.8 & 30.8 & 30.0 & 23.8 & 23.6 \\
Educational, medical and legal & 30.4 & 45.2 & 60.2 & 63.2 & 62.0 \\
Domestic and other services & 12.0 & 12.8 & 7.8 & 5.6 & 7.1 \\
All industries & 29.8 & 33.2 & 32.8 & 29.6 & 29.6 \\
\hline
\end{tabular}

Source: For 1993, Schultz and Mwabu (1997) based on 1993 LSMS dataset. For 1995, 1998 and 2004, own elaboration based on the OHS and LFS.

\footnotetext{
${ }^{16}$ Our series matches the patterns in consumption of durable goods that exhibit a U-shape with its lowest value in 1999.

17 See Banerjee et al. (2007) for wage trends by age, education and race and further discussion.

18 The rate of unionization grew from 5.5 percent in 1980 to 19 percent in 1985 (following the official legalization of unions) to 37 percent in 1993 (Moll, 1993; Schultz and Mwabu, 1997).
} 
in mining, manufacturing, electricity and water and educational, medical and legal services. In most sectors, unionization rates are higher for Africans than for whites (see Schultz and Mwabu, 1997).

The relationship between the union wage premium and labour productivity has ramifications for unemployment. One could imagine that the presence of so many unionized workers might drive up wages faster than productivity growth, thereby exacerbating unemployment. ${ }^{19}$ Here we look mainly at the wages of unionized workers over time in South Africa. Because collective bargained wages might be extended to the non-union workers, our estimates might only capture part of the effect of unions on competitive wages. ${ }^{20}$

We estimated a set of regressions to analyze the evolution of the union wage premium for male salaried employees from 1995 to 2004. In the first column of Table 9 we report a baseline model where we condition on a full set of education, race, age, industry and occupation dummies. ${ }^{21}$ In column 2, following Butcher and Rouse (2001), we include household fixed effects in the model. Thus, the union/ non-union gap is identified only through households with more than one full-time male employee to introduce intra-household variability in union status. Column 3 presents the estimate of adding a public sector dummy to our baseline specification in Column 1. In Column 4 we augment the specification of Column 3 with tenure and tenure squared in the actual job as control variables. Finally, in Column 5 we report an estimate of the union wage gap by the method of stratified matching using the controls in Column 4 to estimate the propensity score. The latter column is our preferred specification because it does the most to control for sample selection bias.

These estimates consistently show that the estimated union wage premium increased during this period. The maximum premium seems to have occurred in 2000 - when employment dampened and wages were at their lowest levels. In 2004, we estimate the union wage gap for African males to be around 23 percent (see column 5) and 17 percent for all males. ${ }^{22}$

\section{Evidence on the speed of transitions}

We now turn our attention to the most recent data and examine some of the dynamics of the South African labour market. One might expect that the relatively stable

\footnotetext{
19 This is especially a problem because collective agreements reached by bargaining councils in South Africa can be extended to all workers and to all firms in an industry (Bendix, 2003).

${ }^{20}$ For 1995, Butcher and Rouse (2001) provide an estimate of the effect of unions on wages of non-unionized workers in sectors with industrial councils on the order of 10 percent while the union-wage premium they estimate is about 20 percent.

${ }^{21}$ We also included province dummies interacted with an urban/rural dummy. This set of controls is included in every regression presented in this section.

${ }^{22}$ In another analysis (not shown) using the specification of Column 4, we found that the wage premium increased for workers with a matric or more, and decreased for those with less than a matric (Banerjee et al., 2007).
} 
Table 9. Estimated coefficients - union wage premium (full-time males only)

\begin{tabular}{|c|c|c|c|c|c|c|c|c|c|c|c|}
\hline & \multirow[t]{2}{*}{ Year } & \multicolumn{2}{|c|}{ Baseline model } & \multicolumn{2}{|c|}{$\begin{array}{c}\text { Baseline model + } \\
\text { household fixed } \\
\text { effects }\end{array}$} & \multicolumn{2}{|c|}{$\begin{array}{c}\text { Baseline model + } \\
\text { public sector } \\
\text { dummy }\end{array}$} & \multicolumn{2}{|c|}{$\begin{array}{l}\text { Baseline model + } \\
\text { dummy and tenure }\end{array}$} & \multicolumn{2}{|c|}{$\begin{array}{l}\text { Stratified } \\
\text { matching }\end{array}$} \\
\hline & & Coefficient & $t$-value & Coefficient & $t$-value & Coefficient & $t$-value & Coefficient & $t$-value & Coefficient & $t$ \\
\hline \multicolumn{12}{|c|}{ Africans only } \\
\hline OHS & 1995 & 0.21 & 14.92 & 0.11 & 2.15 & - & - & 0.18 & 12.87 & 0.14 & 7.61 \\
\hline OHS & 1998 & 0.29 & 12.38 & 0.35 & 3.89 & - & - & 0.25 & 10.38 & 0.20 & 6.97 \\
\hline LFS & 2000 & 0.42 & 23.11 & 0.37 & 4.86 & 0.39 & 20.92 & 0.33 & 17.63 & 0.27 & 11.38 \\
\hline LFS & 2004 & 0.41 & 21.95 & 0.47 & 5.40 & 0.37 & 19.28 & 0.33 & 17.13 & 0.23 & 6.92 \\
\hline \multicolumn{12}{|c|}{ All males } \\
\hline OHS & 1995 & 0.19 & 17.65 & 0.19 & 5.09 & - & - & 0.16 & 14.56 & 0.13 & 8.46 \\
\hline OHS & 1998 & 0.27 & 13.75 & 0.33 & 4.71 & - & - & 0.23 & 11.42 & 0.18 & 6.81 \\
\hline LFS & 2000 & 0.38 & 25.03 & 0.43 & 7.19 & 0.34 & 22.00 & 0.29 & 18.96 & 0.25 & 11.00 \\
\hline LFS & 2004 & 0.35 & 22.88 & 0.52 & 8.11 & 0.31 & 19.96 & 0.27 & 17.41 & 0.17 & 5.73 \\
\hline
\end{tabular}


unemployment rate since 2000 reflects structural inefficiencies in the labour market that hinder transition. However, when we look directly at transitions it becomes clear that this stability hides large gross flows between employment categories. We disaggregate the unemployment data presented in Section 2, and examine transition rates by age, race and education.

For this analysis, we use newly constructed panel data comprising of matched waves of the South African Labour Force Survey (LFS). ${ }^{23}$ The LFS panel is the first nationally-representative panel data on employment in South Africa. It follows individuals over time and permits us to directly observe employment transition. The surveys are conducted bi-annually, with the first wave in February or March, and the second wave in September of each year. From September 2001 (wave 4) to March 2004 (wave 9), the sample involved a rotating panel design, with 20 percent of respondents being rotated out between waves. The cross-sectional sample size is approximately 30,000 households with about 100,000 individual observations; the panel sample size ranges between 45,000 and $71,000 .^{24}$

\subsection{Transition matrices}

The LFS panel data allow us to look at the experience of individuals over time to determine who is making employment transitions and how large the gross flows actually are. Table 10 presents the transition matrix for working-age adults for the six-month period between September 2002 (wave 6) and March 2003 (wave 7).

Table 10. Employment status transition rates for adults (ages 16-64)

\begin{tabular}{lrrrrrrrr}
\hline Wave 6 status & $N$ & Retired & NEA & \multicolumn{2}{c}{ Wave 7 status } & Informal & Formal & Total \\
\cline { 5 - 7 } & & & & Discouraged & Searching & & & \\
\hline Retired & 1,065 & 68.5 & 16.3 & 3.1 & 2.0 & 7.3 & 2.9 & 100 \\
NEA & 7,057 & 2.9 & 68.0 & 9.3 & 12.1 & 4.3 & 3.5 & 100 \\
Discouraged & 2,264 & 1.9 & 19.1 & 36.1 & 28.8 & 9.9 & 4.2 & 100 \\
Searching & 3,630 & 0.8 & 14.2 & 16.4 & 49.8 & 9.3 & 9.5 & 100 \\
Informal & 2,496 & 3.2 & 12.0 & 8.1 & 13.0 & 51.9 & 11.9 & 100 \\
Formal & 6,677 & 0.9 & 3.4 & 1.6 & 5.0 & 4.8 & 84.3 & 100 \\
Total & 23,189 & 4.7 & 26.9 & 10.8 & 17.9 & 11.3 & 28.4 & 100 \\
\hline
\end{tabular}

${ }^{23}$ See Appendix A in Banerjee et al. (2007) for a more detailed description of the data.

${ }^{24}$ Each wave comes with a set of sampling weights, which we used in generating all of our results. The weights correct for potential over-sampling of certain sub-populations, as well as for differential rates of non-response. 
These transition matrices for wave 6 to wave 7 are broadly representative of the other wave-to-wave transitions in the panel. ${ }^{25}$ The transition probabilities in the matrix show, for example, that

- Of adults 16-64 who are unemployed (and either discouraged or searching), 9.6 percent find employment in the formal or informal sector after six months.

- Discouraged workers most frequently transition into actively searching for work. About 14 percent transition from discouraged and reportedly not searching for work, to employed six months later.

- Discouraged workers are twice as likely to transition into the informal as the formal sector, while the unemployed who are searching are equally likely to transition into the informal or formal sectors. Almost 12 percent of those who are initially working in the informal sector transition within six months to the formal sector.

- Of those with formal sector employment, only 16 percent have transitioned into another state after six months with the other 84 percent staying in the formal sector.

- So-called retirement is apparently not a permanent (absorbing) state. Of those who are retired in wave 6 , only about 68 percent are classified as retired six months later. This is perhaps an artefact of how data were recorded, since another 16 percent were classified as not economically active (NEA) six months later. Even if all the NEA were in fact still retired, there are 15 percent of the so-called 'retired' who are either looking for work or working six months on.

Most importantly, we are struck by just how much churning there appears to be in the labour market. Although the aggregate unemployment figures in Table 1 show little change from LFS wave to wave, the individual-level data show remarkable mobility. Examples include:

- Only about half of the workers who are employed in the informal sector are still employed there six months later.

- Half of the workers who are listed as formally searching for a job are still searching six months later.

- Only about a third of the workers who list themselves as discouraged are so listed six months later.

- Even among the NEA, about 30 percent no longer report being in that category after six months.

Rather than a sclerotic labour market where individuals tend to stay in the same employment category from wave to wave, the transition data suggest a high level of mobility at the individual level. One concern that we had is that this reflects the

\footnotetext{
${ }^{25}$ Transitions matrices for a one-year period were generally similar as well. For brevity we do not present
} these results here. 
Table 11. Employment status transition rates for youth (ages 16-24)

\begin{tabular}{lrrrcrrrr}
\hline Wave 6 status & N & NEA & & \multicolumn{2}{c}{ Wave 7 status } & & Formal & Total \\
& & & Discouraged & Searching & Informal & & \\
\hline NEA & 4,318 & 78.2 & 7.5 & 11.1 & 1.7 & 1.4 & 100 \\
Discouraged & 722 & 21.8 & 37.3 & 31.9 & 6.0 & 3.0 & 100 \\
Searching & 1,062 & 18.5 & 16.9 & 52.3 & 4.7 & 7.5 & 100 \\
Informal & 213 & 31.5 & 14.6 & 17.7 & 27.8 & 8.4 & 100 \\
Formal & 512 & 5.2 & 6.3 & 13.8 & 3.6 & 71.1 & 100 \\
Total & 6,827 & 53.9 & 12.8 & 21.1 & 3.8 & 8.4 & 100 \\
\hline
\end{tabular}

burden of HIV/AIDS. Perhaps people are forced to transition out of the labour market when they get very sick and return when they are in remission. This does not appear to be the case. We can use the LFS data to identify those who changed the labour market status because of their own illness. The results remain qualitatively similar when we leave them out: only the percentage of workers listed as retired or NEA change slightly. ${ }^{26}$

There is no clear pattern of transition from the informal sector to the formal sector, as is observed in many other developing countries. ${ }^{27}$ An equal proportion transition from the informal sector into unemployed and searching as transition into the formal sector. ${ }^{28}$

Table 11 gives transition probabilities for South African youth (ages 16-24 inclusive). We identify two reasons for high unemployment rates among young people: low outflows because searching is not very successful, and high inflows because, for example, high school dropouts go directly into unemployment and are likely to remain there. Those between the ages of 16-24 who are searching for a job are much more likely to transition into discouraged worker status than they are to obtain employment (in the formal or informal sector). Of the youth classified as NEA in wave 6 (most of whom are students), about 22 percent transition out of NEA within six months - 18.5 percent into unemployment and only 3 percent into employment. One policy response to this situation is for the government to induce

\footnotetext{
${ }^{26}$ One caveat is that the data do not allow us to identify individuals who transition because they are caring for family members ill with AIDS.

27 Respondents were determined to be in the informal or formal sector based on a series of questions about whether the employer was registered, paying UIF for the employee or paying VAT. The vast majority of unionized jobs are found in the formal sector, not in the informal sector.

${ }^{28}$ However, men transition into the formal sector at a higher rate (16.5 percent) than women do (8.5 percent). See Banerjee et al. (2007).
} 
firms to create special low wage jobs for younger workers. Despite potential opposition from the unions, which are allied with the ruling party, such an institutional arrangement does exist in South Africa (it is called a learnership) and it is in fact subsidized. However, it is unclear how widespread the take-up of this program has been. A careful analysis of this existing program, in light of the persistent unemployment concentrated among the younger workers, seems appropriate.

The retention rate in the informal sector is low among youth (28 percent) suggesting that this is likely to be casual (temporary) employment rather than a more permanent attachment to the informal sector. Only about 8.5 percent of youth in the informal sector transition into the formal sector between waves 6 and 7 . They are less likely to transition into the formal sector than they are to transition into any other employment category. These analyses of youth transition probabilities all point to the potential benefits of getting young workers into their first job. The school-to-work transition is key and it simply is not working at present.

Table 12 presents labour market transitions for Africans and whites. We discuss outcomes for Coloureds and Indians but do not show those matrices here. ${ }^{29}$

Table 12. Employment status transition rates for adults by race (ages 16-64)

\begin{tabular}{lrrrrrrrr}
\hline Wave 6 status & N & Retired & NEA & \multicolumn{2}{c}{ Wave 7 status } & Informal & Formal & Total \\
\cline { 6 - 7 } & & & & Discouraged & Searching & & & \\
\hline African & & & & & & & & \\
Retired & 753 & 66.8 & 15.8 & 3.7 & 2.2 & 9.9 & 1.7 & 100 \\
NEA & 5,425 & 2.4 & 67.8 & 10.7 & 12.6 & 4.7 & 1.8 & 100 \\
Discouraged & 2,028 & 1.7 & 18.7 & 37.3 & 28.6 & 10.1 & 3.6 & 100 \\
Searching & 3,121 & 0.7 & 13.6 & 17.3 & 51.1 & 9.1 & 8.2 & 100 \\
Informal & 2,196 & 3.3 & 11.7 & 8.8 & 13.5 & 53.0 & 9.7 & 100 \\
Formal & 3,743 & 0.5 & 2.9 & 2.2 & 6.7 & 5.8 & 81.9 & 100 \\
Total & 17,266 & 4.2 & 28.1 & 13.2 & 20.7 & 13.0 & 20.9 & 100 \\
White & & & & & & & & \\
Retired & 142 & 76.6 & 13.2 & 1.0 & 0.4 & 0.6 & 8.2 & 100 \\
NEA & 500 & 5.1 & 71.6 & 2.6 & 5.4 & 2.4 & 12.9 & 100 \\
Discouraged & 33 & 19.5 & 30.9 & 23.4 & 5.5 & 0.0 & 20.7 & 100 \\
Searching & 61 & 5.3 & 18.7 & 8.1 & 31.1 & 11.8 & 24.9 & 100 \\
Informal & 61 & 2.1 & 13.4 & 0.0 & 6.3 & 18.8 & 59.4 & 100 \\
Formal & 1,327 & 1.9 & 4.4 & 0.7 & 1.4 & 2.6 & 89.0 & 100 \\
Total & 2,124 & 8.3 & 20.6 & 1.7 & 3.4 & 3.2 & 62.9 & 100 \\
\hline
\end{tabular}

${ }^{29}$ See Banerjee et al. (2007). 
Outcomes for African workers are generally worse than for the other population groups: they are more likely to remain in the informal sector, less likely to transition from the informal sector into the formal sector, and less likely to retain formal sector employment should they obtain it. The informal sector can be characterized as a second-best alternative to formal employment - the returns to education are generally lower than in the formal sector. While only 19 percent of whites in the informal sector remain there after six months, over 50 percent of Africans and Coloureds, and 43 percent of Indians do. About 60 percent of whites in the informal sector transition to the formal sector after six months; the corresponding figure for Coloureds and Indians is about 20 percent, and for Africans is below 10 percent. African workers are proportionally less likely to retain a formal sector job than are other races. In a six-month period, whites are about 7 percentage points more likely than Africans to remain in the formal sector, while Coloureds and Indians are about 4 percentage points more likely than Africans to do so. If we condition on gender, age, education level, urban/rural and whether the individual has held a job before, the gap between whites and Africans is only reduced slightly to 5.5 percent (results not shown).

Job search is more effective for whites and Indians than it is for Africans and Coloureds. Of those who are actively job searching, 50 percent of Africans and 45 percent of Coloureds are still searching after six months, whereas only 30 percent of whites and Indians remain in this state. Africans are more likely to move from actively searching to either discouraged or NEA than into employment, while the other population groups are more likely to move into employment in the formal sector or NEA than into the other categories. It is troubling that as many as 17 percent of Africans who are actively searching for a job transition into discouragement within six months. This raises questions about the efficacy of various search methods and the reasons why so many Africans transition into discouragement.

The proportion of discouraged workers in the labour force has been growing, with African workers comprising a larger portion of discouraged workers over time. ${ }^{30}$ Discouraged worker status is a much more sticky employment status for Africans than for the other population groups: 50 percent remain discouraged six months later, while this figure is approximately 23 percent for Coloureds and whites, and only 12 percent for Indians. A troubling statistic is the magnitude of the outflow of Africans from the formal sector directly into the discouraged worker category - HIV/AIDS may be part of the explanation for this. Levinsohn et al. (2008) present evidence in support of this.

\subsection{Summary}

The results from this section suggest that the bulk of the unemployment is structural rather than transitional. This does not mean that there are no transitional

${ }^{30}$ LFS 2000-2005, Broad definition of unemployment. 
elements in what we observe. Nor should we conclude that the elements identified in this section, such as search costs, are unimportant. But if they play a role, it is not so much because the economy is in transition, but because they interact with other structural features of the economy.

The great deal of churning in the labour market presents two avenues for policy: increase the inflow into the formal sector and/or slow the outflow out of it. The labour market appears to be very near the steady state so it is unlikely that the unemployment rate will fall without intervention or an external shock. This evidence does not tell us whether these transitions out of the formal sector are voluntary quits or lay-offs (although anecdotal evidence suggests they are the former), but high turnover in the workforce generally leads to a sub-optimal level of investment in firm- or industry-specific human capital on the part of workers and the employers. On the other hand, workers seem to have a reasonable chance of finding jobs, but the large bi-directional flows may be hiding changes in the skill composition of the formal sector discussed in section 3. If firms have been upgrading the skill level of their labour force as real wages remain stable, then we may have a more sclerotic labour market than it seems, as one set of people lost their jobs and a very different set gained.

\subsection{Search}

Search costs are an underlying reason why unemployment and the informal sector are more 'sticky' labour market outcomes for some groups than for others. ${ }^{31}$ As shown above, Africans and Coloureds are more likely to remain searching than whites or Indians. The differential effectiveness of search may be accounted for by the legacy of apartheid-era spatial separation between Black job seekers and the centres of business and industry where the jobs are. Workers from surrounding areas need to search for jobs far from their homes, and this is generally a major discouragement. To make matters worse, the lack of high-density urban centres make the costs of job search particularly high in South Africa, thereby reducing the effectiveness of the job search of a large part of the population and increasing the equilibrium unemployment rate.

The history of racial prejudice may be another reason why search is a particular problem in South Africa. Kingdon and Knight (2004a) find that about one-third of the African/Coloured/Indian-white unemployment gap remains unexplained after controlling for observable characteristics. Discrimination is one factor that probably plays a role in the remaining gap. As known from the work of Diamond (1984), search models admit multiple equilibria with differing levels of search, and a small amount of prejudice could tip the equilibrium towards the inefficient low search equilibrium (or shift the unique equilibrium towards the low search outcome).

${ }^{31}$ See Banerjee et al. (2007) for a more detailed discussion of these issues. 
High search costs could in principle explain high levels of transitional unemployment when combined with the fact that the demand and supply of labour in South Africa had shifted enormously during this period, making large reallocations necessary. High search costs would slow down this transition, though whether that increases or decreases unemployment depends on whether, on balance, this leads to more time spent searching.

\subsection{The informal sector}

Another way in which many sub-Saharan African countries often deal with rigidities in the formal sector labour market is through a burgeoning informal sector. South Africa, though, has a relatively small informal sector relative to its African neighbours. One reason this might be the case is that a spirit of entrepreneurship was actively discouraged for decades under apartheid. This history may help explain why the informal sector has not grown as quickly as one might otherwise expect. $^{32}$ The transitions evidence in Table 10 shows that the informal sector does not act as a 'springboard' into the formal sector for very many people.

\subsection{Reservation wages}

Unemployment is especially high among workers under the age of 35, and most of these unemployed young people have never worked before. One possible interpretation of this phenomenon is that people claim that they want a job and are looking, but really are not, either because they are looking for a job that is not there (a job that would pay them a lot or one that is in their backyard) or because they are putting very little effort into their job searches. In other words, they are not looking for the job that they can get.

Why might this be a particular problem in South Africa? One answer is that South Africa's social pension program is particularly generous, paying each senior South African something of the order twice the per capita income. ${ }^{33}$ No other middleincome country has a comparable program. This is a result of extending the very generous apartheid-era pension program for whites to the rest of the population.

\subsubsection{Pensions and reservation wages}

One consequence of this program is that many unemployed South Africans can survive without having to take a job, as long as their elders are willing to support them. This would mean that they might put less effort into job search and be fussier about jobs they take. There is some evidence that this is indeed a problem. Bertrand, Mullainathan and Miller (2003), using data from the mid-1990s, show

32 See Kingdon and Knight (2007) for a further discussion of why the informal sector may be underdeveloped.

${ }^{33}$ Despite being means-tested, the pension has near-universal coverage of elderly South Africans. 
evidence that people who have family members who are eligible for the pension tend to work less than they would otherwise. More recent (and perhaps more convincing) evidence is provided by Ranchhod (2007). His article analyzes the change in employment and labour force participation rates using the panel components in the LFS. He investigates whether the loss of a pensioner generates a corresponding increase in labour force participation. He finds an increase in employment rates amongst adults, particularly adult women, of between 5 and 6 percentage points. In the high unemployment context already described, this is a large and economically important increase. This might also explain the particular age structure of unemployment - perhaps people start looking seriously for a job when their parents die (or are dying), which is why people above thirty are more likely to be employed. People above thirty are also much more likely to be married and/or have children, which might also make it harder for them to depend on their parents. ${ }^{34}$ Indeed, Klasen and Woolard (2008) find that household formation is sensitive to old age pension income, potentially drawing the unemployed away from employment opportunities.

\subsubsection{Education, expectations and reservation wages}

Another reason why South Africa is different from many other countries is that there has been an enormous transformation of the structure of the labour force over the last 15 years. The implementation of the compulsory schooling laws has meant that almost all of the younger workers now have 10 years or so of education, whereas many of those who grew up under apartheid only had a few years of education. This means that the return to schooling and the benefits of having matriculated have probably fallen substantially. If the newly educated workers have not yet understood this, they may be holding out for jobs that are no longer going to be available to them. This may be why younger workers and especially matriculates among them have done so badly in recent years in terms of employment.

\subsubsection{Employment attitudes and reservation wages}

Despite the general plausibility of a high reservation wage being a constraint a number of scholars have argued against this possibility. ${ }^{35}$ In the LFS waves, all persons who were not working in the past seven days were asked why they were not working. Reservation wages do not seem to be an important part of the story. From age 20 to 50, the most common reason provided is that people cannot find any work. Indeed, from age 20 to 40, over half of the respondents chose this

\footnotetext{
${ }^{34}$ See also Banerjee et al. (2007) for an extended discussion.

${ }^{35}$ For example, Nattrass and Walker (2005) find that reservation wages in a working-class suburb of Cape Town match predicted wages fairly closely. Also, Kingdon and Knight find that the unemployed are less happy (2004b) and that job search and happiness are not both determined by some unobserved factor (2006b). If unemployment were voluntary, we would expect the unemployed to be as happy as the employed, and discouraged workers to be as happy as the searching unemployed.
} 
category. ${ }^{36}$ Taken by itself it argues against the reservation wages view, but it is not clear that we can infer from these answers that they have seriously looked for and not found a job.

\subsection{Summary}

Our analysis of transitions demonstrates that there is a lot of churning going on in the labour market. We suspect there is selective churning: the characteristics of workers in the inflow to and outflow from the formal sector, for example, are probably not identical. However, we are unable to capture the nature of the sorting with the demographic variables we included in our analysis. Transition from the informal sector to the formal sector is more likely for more advantaged groups (whites, men, those with more education). This evidence suggests that in addition to the skill-composition changes documented in Section 2, employers may be more selective along other dimensions of quality (experience, for example) that put the currently unemployed at even more of a disadvantage.

Despite the high rate of transition, many young workers do not transition into the labour force and instead remain unemployed (discouraged or searching) for long periods. The inability of these workers to enter the labour force and obtain their first job suggests an important role of high search costs, compounded by high turnover in the labour market (which reduces the incentive to invest in search), and of high reservation wages due to family support.

\section{Conclusion}

We noted at the outset that changes in the unemployment rate could be viewed as resulting from either a temporary shock or a more permanent structural change. We proceeded by using several nationally representative household surveys to investigate multiple aspects of South African unemployment. On the more aggregate level, we noted that the demand for unskilled labour had fallen and that this was particularly manifested in the agricultural and mining sectors. Concurrent with the decline in the demand for less-skilled labour, there was a large increase in the supply of less skilled labour. Much of this increase was in the form of a large influx of African women into the labour market. The result of the increased supply and decreased demand was, predictably, increased unemployment.

We view the massive influx of female labour supply as a structural change, not a temporary shock. There is simply no evidence to suggest that women are likely to exit the labour market in the sort of numbers that entered any time soon. Similarly,

\footnotetext{
${ }^{36}$ Note that this is not that they cannot find suitable work, in terms of 'salary, location or work conditions', as this was captured by a separate answer choice.
} 
there is little reason to expect that agriculture or mining are likely to become more labour intensive. The fact that mining employment has fallen rather steadily during the recent commodity boom leads us to believe that the decline in mining employment is also a structural shift rather than a transitory shock. Finally, the decline in agricultural employment also strikes us as a structural shift. The South African economy has moved into sectors such as financial services and other service sectors, and agriculture is on the downswing.

In Section 3, we noted that there have been important compositional changes in employment at the sectoral level. In particular, the pool of the employed has tended to become more skilled while the less skilled have more often become relegated to the ranks of the unemployed. This is a global phenomenon and is in no way unique to South Africa. Many economists attribute these sectoral changes to skill-biased technical change, which has impacted South Africa at an especially inopportune time, for it tends to amplify the unemployment consequences of the increase in labour supply of unskilled workers.

Section 4 turned more closely to the individual-level evidence and explored how workers have adjusted (or not) to the changing labour market that is highlighted in Sections 2 and 3. There we found that examining the employed/unemployed dichotomy is too simple. Among the employed, it matters if one is in the formal or informal sector and among the unemployed, the actively searching versus discouraged worker distinction matters a great deal to outcomes. We examined the likelihood of transitions from one labour market status to another, and the results are especially informative for policy. For example, the data indicate that there is substantial entry into and exit from the informal sector, but transitions are typically to some form of unemployment or lack of labour market participation. Transitions from the informal sector to the formal sector are surprisingly rare. The transitions results are especially stark when it comes to youth. Obtaining that first job is crucial to future involvement in the labour market. It appears to be exceedingly difficult for many, and simply having a matric degree is of little help.

Because most of the reasons for unemployment are structural, policy is especially needed. Simply waiting for the positive 'shock' to counter the negative one is unlikely to be fruitful. Neither do we believe that macroeconomic policy is likely to solve the unemployment problem. Were unemployment the result of a temporary easing of demand, this might make sense, but, as noted above, our analysis points to structural causes of the rise in unemployment.

We have restricted ourselves in this article to analysis that is supported by the data. An implication of this research strategy is that we have not engaged in much 'big think' speculation on what might solve the unemployment dilemma. Some constraints are especially prominent and deserve policy consideration. One of these is the hurdle of school-leavers obtaining their first job. There are several policy options including a wage subsidy, a search subsidy, reduced regulations for first jobs, and government employment. Another constraint is the mismatch between where the unemployed live and where formal sector jobs are located. Here policy 
options include transportation subsidies, housing policy, business location policy, and infrastructure investment, among others. Yet another constraint is the mismatch between the skill set of the unemployed and the skills required in the labour market. Training programs and training subsidies are short-term remedies, however they might only succeed in reordering the queue of job seekers. In the longer run, educational reform will be required to ease the mismatch and increase human capital. At this point, our analysis is simply insufficient to distinguish between the many options that might plausibly ease each constraint. Rather, we advocate a cautious approach that includes a focus on experimentation. We believe that much can be learned from smaller-scale interventions that are well designed and which are accompanied by careful evaluation. That is the prudent next step.

\section{References}

Alleyne, T. and Subramanian, A. (2001). 'What does South Africa's pattern of trade say about its labor market?' IMF Working Paper, 01/148, Washington, DC: IMF.

Banerjee, A., Galiani, S., Levinsohn, J., McLaren, Z. and Woolard, I. (2007). 'Why has unemployment risen in the New South Africa?' NBER Working Paper 13167, Cambridge, MA: NBER.

Bendix, S. (2003). Industrial Relations in South Africa, 4th edn, South Africa: Juta.

Bertrand, M., Mullainathan, S. and Miller, D. (2003). 'Public policy and extended families: Evidence from pensions in South Africa', World Bank Economic Review, 17(1), pp. 27-50.

Bhorat, H. (2000). Decomposing Sectoral Employment Trends in South Africa, Cape Town: Development Policy Research Unit (DPRU), School of Economics, UCT. Mimeo.

Bhorat, H. (2004). 'Labour market challenges in the post-apartheid South Africa', South African Journal of Economics, 72(5), pp. 941-977.

Burger, R. and Yu, D. (2006). 'Wage trends in post-apartheid South Africa: Constructing and earnings series from household survey data', Stellenbosch Economic Working Papers: 04/ 06.

Butcher, C. and Rouse, C. (2001). 'Wage effects of unions and industrial councils in South Africa', Industrial and Labor Relations Review, 54, pp. 349-374.

Casale, D. and Posel, D. (2002). 'The continued feminisation of the labour force in South Africa: An analysis of recent data and trends', South African Journal of Economics, 70(1), pp. 156-184.

Casale, D., Muller, C. and Posel, D. (2004). 'Two million net new jobs: A reconsideration of the rise in unemployment in South Africa, 1995-2003', South African Journal of Economics, 72(5), pp. 978-1002.

Diamond, P. (1984). 'Money in search equilibrium', Econometrica, 52, pp. 1-20.

Hoogeveen, J. G. and Özler, B (2005). 'Not separate, not equal: Poverty and inequality in post-apartheid South Africa', William Davidson Institute Working Papers Series wp739, William Davidson Institute at the University of Michigan Stephen M. Ross Business School, Cambridge, MA: WDI.

Kingdon, G. and Knight, J. (2004a). 'Race and the incidence of unemployment in South Africa', Review of Development Economics, 8(3), pp. 198-222. 
Kingdon, G. and Knight, J. (2006a). 'How flexible are wages in response to local unemployment in South Africa?' Industrial and Labor Relations Review, 59(3), pp. 471-495.

Kingdon, G. and Knight, J. (2006b). 'The measurement of unemployment when unemployment is high', Labour Economics, 13(No. 3), pp. 291-315, June 2006.

Kingdon, G. and Knight, J. (2007). 'Unemployment in South Africa, 1995-2003: Causes, problems, and policies', Journal of African Economies, 16(5), pp. 813-848.

Kingdon, G. G. and Knight, J. (2004b). 'Unemployment in South Africa: The nature of the beast,' World Development, 32(3), pp. 391-408.

Klasen, S. and Woolard, I. (2008). 'Surviving unemployment without state support: Unemployment and household formation in South Africa', Journal of African Economies, forthcoming.

Leibbrandt, M., Levinsohn, J. A. and McCrary, J. (2005). 'Incomes in South Africa since the fall of apartheid', NBER Working Paper No. W11384, Cambridge, MA: NBER.

Levinsohn, J., McLaren, Z., Shisana, O. and Zuma, K. (2008). HIV Status and Labor Market Participation in South Africa, Ann Arbor, MI: University of Michigan, Mimeo.

Moll, P. G. (1993). 'Black South African Unions: Relative effects in international perspective', Industrial and Labor Relations Review, 46(2), pp. 245-261.

Nattrass, N. and Walker, R. (2005). 'Unemployment and reservation wages in working class Cape Town', South African Journal of Economics, 73(3), pp. 498-509.

Ranchhod, V. (2007). 'Household responses to adverse income shocks: Pensioner out-migration and mortality in South Africa', African Econometrics Society Conference 2007, Cape Town, Western Cape, South Africa. July 4-6, 2007.

Schultz, P. and Mwabu, G. (1997). 'Labor unions and the distribution of wages and employment in South Africa', Industrial and Labor Relations Review, 51(4), pp. 681-703. 